\title{
The Representation of Islamic Values in The Novel "The Fading of Cleopatra's Charm" by Habibburrahman El Shirazy
}

\author{
Indiyah Prana Amertawingrum ${ }^{1}$, Ngumarno ${ }^{2}$, Sri Budiyono ${ }^{3}$ \\ 1, 2, 3 Faculty of Teacher Training and Education, Widya Dharma University \\ sribudiyono15@gmail.com
}

\begin{tabular}{ll}
\hline Article History & Received : January $11^{\text {th }} 2021$ \\
& Revision : Marchy $17^{\text {th }} 2021$ \\
& Publication : June $30^{\text {th }} 2021$ \\
\hline
\end{tabular}

\begin{abstract}
This study aims: (1) to find Islamic values contained in the novel "Pudarnya Pesona Cleopatra" by Habibburrahman El Shirazy; and (2) describe the form of representation of Islamic values contained in the novel "The Faded of Cleopatra's Enchantment" by Habibburrahman El Shirazy. This study used descriptive qualitative method. The data are in the form of words and phrases contained in the "The Faded of Cleopatra's Enchantment" by Habibburrahman El Shirazy which reveals information about Islamic values that come from the Al Qur'an and Hadith. Based on the results of the analysis that has been done, it can be concluded that the Islamic values contained in the novel 'Faded Pesona Cleopatra' include the values of Akidah, Sharia, and morals. These values are represented in the story in the form of faith in Allah; Faith in the Bible (Al Qur'an) for the value of faith. Sharia values are represented in the form of sunnah fasting; propose (khitbah); wedding; while moral values are represented in the form of personal morals, namely the nature of patience; as well as character in the family which includes obedience and filial piety to parents; pious and obedient to her husband; as well as connecting kinship/friendship ties.
\end{abstract}

Keywords: representation, Islamic values, the fading of Cleopatra's charm

\section{INTRODUCTION}

Literary works are the result of the author's imagination that cannot be separated from the realities of life. Through various experiences, tracing, observing the problems of life and living around him, the author performs contemplation and contemplation in order to produce a work. Therefore, a literary work will always carry the cultural context of a particular society that inspires authors to write literary works. Literary works are the result of the author's imagination that cannot be separated from the realities of life. Through various experiences, tracing, observing the problems of life and living around him, the author performs contemplation and contemplation in order to produce a work. Therefore, a literary work will always carry the cultural context of a particular society that inspires 
authors to write literary works.

What is contained in literary works is an expression of the human person in the form of experiences, thoughts, feelings, ideas or ideas, the spirit of belief or belief in a form of a concrete picture of life that is expressed through language tools. That way, a good literary work always shows the unity of its elements, namely the harmony between the content, form, language and personal expression of the writer. As a literary work, a novel has elements of building work, namely intrinsic elements and extrinsic elements. Intrinsic elements are elements that build literary work itself (Nurgiyantoro, 2013: 30). The elements in question are story events, plots, characterizations, themes, settings, storytelling points of view, language and language style.

Habiburrahman El Shirazy is an Indonesian writer whose presence in the literary world has been phenomenal. He is not only known as a writer, but also as a da'i, poet, novelist, humanist, and director. As a writer, Habiburrahman El Shirazy has made amazing and spectacular achievements through various works that were born from his hands.

Knowing, understanding, understanding, and practicing Islamic teachings seriously are certainly a dream for a Muslim. Furthermore, a good Muslim certainly also tries to convey, instill, and transform the Islamic values that he believes in to other people or future generations. Therefore, in the person of a Muslim there are values that are based on and imbued with faith and devotion to Allah SWT through His Kalam in the form of the Al Qur'an as the source of all sources of value which are absolute to be obeyed. This also seems to inspire Habiburrahman El Shirazy in his work.

Habiburrahman El Shirazy's works are full of Islamic values. This is in accordance with his wish to make the novels he wrote as wajihah or a means of grounding the holy verses of the Al Qur'an, so that the Al Qur'an can really live and become a life guide that can be practiced in everyday life. The novel 'Faded Pesona Cleopatra' was chosen from the point of view of Islamic values because in it there are many Islamic values which represent Islamic teachings that come from the $\mathrm{Al}$ Qur'an as an absolute source in life and represent the sunnahs of the Prophet Muhammad found in the Hadith. Islamic values derived from the Al-Quran and Hadiths are very intense in this novel. This fact encourages researchers to find out more about how the author represents Islamic values in the novel 'Faded Pesona Cleopatra'.

The problems in this research are (1) what Islamic values are represented in the novel "The Fading of Cleopatra's Charm" by Habibburrahman El Shirazy; and (2) How is the representation of Islamic values in the novel "Faded Enchantment of Cleopatra" by Habibburrahman El Shirazy.

This study aims to: (1) find Islamic values contained in the novel "Pudarnya Pesona Cleopatra" by Habibburrahman El Shirazy; and (2) describe the form of representation of Islamic values contained in the novel "Faded Enchantment of 
Cleopatra" by Habibburrahman El Shirazy.

The term representation is often associated with human life. In KBBI, representation / re • pre $\bullet$ sen $\bullet$ ta $\bullet$ si / / répréséntasi / n 1 act represents; 2 states are represented; 3 what it represents; representation (https://kbbi.web.id/representasi. It shows that representation is related to the representation or representation of a concept or idea that can be absorbed by reason and then re-expressed by using language media. Representation with respect to the representation or representation of a concept or ideas that can be absorbed by reason and then re-expressed by using language media. In general, value can be interpreted as an idea regarding what is considered good, beautiful, worthy, desired and expected by all people in life.

This is in line with what was conveyed by Erlina \& Abdurahman (2018: 4-5) that value is the quality of something that is liked, wanted, valued, useful and makes people who live with dignity. In addition, values can also refer to certain behaviors that refer not only to correct behavior, but also to incorrect behavior. As Richard (in Herimanto and Winarno, 2008: 126) argues about value, value is a collective idea of what is considered good, important, desirable and appropriate. He further stated that value does not only relate to everything that is considered good. Value refers to something that is considered valuable, good and bad in human life, both as an individual and as a social being.

Islamic values cover all aspects of life, both relating to the relationship between humans and the Creator, human relations with fellow humans, and human relations with their surroundings. The dimensions of human life contain Islamic ideal values which can be grouped into three categories, namely worldly dimensions, dimensions, ukhrowi, and ukhrowi worldly dimensions.

The worldly dimension is a dimension that contains values oriented towards pleasure, the welfare of life in the world. The ukhrowi dimension is a dimension that encourages humans to gain happiness in the hereafter, while the worldly dimension of ukhrowi is a combination of worldly and ukhrawi dimensions (Arifin, 1993: 120). Of the three dimensions, the worldly dimension of ukhrowi which focuses on the balance and harmony of life in the world and the hereafter is the ideal foundation that needs to be prioritized in the person of a Muslim.

As a form of literary work, novels have a different form from other literary works such as poetry and drama. Novels also allow the presentation at length about a certain place (space) (Sayuti, 2000: 11).

Novel is a literary genre built by elements. This is in line with the opinion of Waluyo (2002: 136) which states that fictional stories are discourses constructed by several elements. These elements build unity, unanimity, and self-regulation or build a structure. These elements are functional, meaning that they are created by the author to support the overall purpose and the meaning is determined by the whole story.

From the above opinion, it can be stated that a novel is a fictional story created 
by the author with a series of stories and built by the building blocks. In addition, as a literary work, the novel contains various values that the author wants to convey to his readers. This means that the novel is not free of value.

\section{METHOD}

This research is a qualitative research, namely research that produces descriptive data in the form of written or spoken words from people and observable behavior (Bogdan and Taylor in Muhammad, 2011: 30).

In examining the representation of Islamic values in the novel "Pudarnya Pesona Cleopatra" by Habibburrahman El Shirazy, a descriptive analytical method is used. This method is carried out by describing the facts which is then followed by a semiotic analysis to find Islamic values that are represented in the novel.

The data in this study are in the form of words, phrases contained in "Faded Enchantment of Cleopatra" by Habibburrahman El Shirazy which reveal information about Islamic values sourced from the Al Qur'an and Hadith. In addition, data is also used to reveal signs that represent Islamic values. In literary research, data sources are in the form of novel texts, short stories, and others (Siswantoro, 2010: 63). The data source of this research is the novel "The Fading of Cleopatra's Charm"by Habibburrahman El Shirazy which was published in March 2018 by the publisher Republika with a thickness of 46 pages.

In this research, the researcher acts as the main instrument, meaning that the researcher is directly involved in observing, observing, exploring, and at the same time justifying the data contained in the novel "Pudarnya Pesona Cleopatra". This is in accordance with the statements and opinions of Sukardi (2013: 14), which states that qualitative research plays a direct role in investigating, observing, identifying, with the intention of explaining and predicting symptoms that occur or events in the field. The supporting instruments in this study were a data collection guide and a data analysis guide as well.

The analysis technique used is to use qualitative descriptive analysis. This type of qualitative descriptive research displays data results as they are without any manipulation or other treatment process, while the main objective is to produce an accurate picture of a group, describe the mechanism of a process or relationship, provide a complete picture in either verbal or numerical form, present basic information about a relationship, creating a set of categories and at the same time classifying research subjects.

\section{RESULTS AND DISCUSSION}

Based on the data on Islamic values presented in the table above, the following will describe a discussion of them. However, so that the meaning of the representation of Islamic values contained in the novel can and is easily understood as a whole, unanimously and thoroughly, the discussion is not based on the order of values listed in the table, but is based on storylines, characterizations, and elements. the story that built it.

The story in the novel "Pudarnya Pesona Cleopatra" opens with the wish of the 
character "Aku" to marry off "Aku" to a woman, Raihana, the son of his girlfriend in Mangkuyudan, Solo.

"Ibunya Raihana adalah teman karib ibu waktu nyantri di Mangkuyudan Solo dulu," kata Ibu.

"Kami pernah berjanji, jika dikaruniai anak berlainan jenis akan besanan untuk memperteguh tali persaudaraan. Karena itu Anakku, ibu mohon keikhlasanmu." (PPC/Pudarnya Pesona Cleopatra, hal. 1)

"Raihana's mother was a close friend of my mother when she was studying in Mangkuyudan Solo," said Ibu.

"We have promised that if you are blessed with children of different types, you will order to strengthen your brotherhood. Because it is my son, mother begs your sincerity. " (PPC, p. 1)

This was done with the aim of connecting/strengthening the relationship. What is the wish of the mother of the character 'I' is a form of representation from the sunnah of the Prophet Muhammad who advocated connecting ties (HR. Bukhari 2067, Muslim 2557, and An-Nawawi 16/89).

Considering that there are so many rewards that can be gained from continuing the relationship, and the sin of those who cut off the friendship, then the relationship should not be broken. In fact, it is advisable to reconnect the relationship that has been severed.

Apart from the reason for strengthening the relationship, the mother also knew exactly the lineage and piety of Raihana's parents. Likewise with Raihana. She was a kind, friendly, refined girl, undergraduate, patient, veiled, and memorized the Al Qur'an (PPC, p. 2).

"Mbak Raihana itu orangnya baik kok, Kak. Dia ramah, halus budi, sarjana pendidikan, penyabar, berjilbab, dan hafal Alquran lagi. Pokoknya cocok deh buat Kakak." (PPC, hal. 2).

"Mbak Raihana is a good person, Sis. She is friendly, refined, has a degree in education, is patient, veils, and memorizes the Al Qur'an again. Anyway, it fits Brother. " (PPC, p. 2).

Because of my devotion to my mother and not wanting her mother to be disappointed, even though with a heavy heart, I am willing to marry Raihana, by first proposing/proposing.

"Dalam pergulatan jiwa yang sulit berhari-hari, akhirnya aku pasrah. Aku menuruti keinginan ibu. Aku tak mau mengecewakan ibu. Aku ingin menjadi mentari pagi di hatinya, meskipun untuk itu aku harus mengorbankan diriku." (PPC, hal. 2).

"Saat khitbah sekilas kutatap wajah Raihana, dan benar kata si Aida, ia memang baby face dan lumayan anggun. (PPC, hal. 3).

“... Ingin aku memberontak pada ibu. Tapi teduh wajahnya selalu membuatku luluh." (PPC, hal. 4). 
"Aku benar-benar merana. Satu-satunya, harapanku hanyalah berkah dari Tuhan atas baktiku pada ibu yang amat kucintai. Rabbighfirli wa liwalidayya!"(PPC, hal 5)

"In a struggle for my soul for days, I finally gave up. I obeyed mother's wishes. I don't want to disappoint you. I want to be the morning sun in his heart, even though for that I have to sacrifice myself. " (PPC, p. 2).

"During the sermon, I glanced at Raihana's face, and it was true that Aida said, she was indeed a baby face and quite graceful. (PPC, p. 3).

“... Want me to rebel against mother. But the shade of his face always makes me melt. " (PPC, p. 4).

"I'm really sad. The only thing, my hope is only a blessing from God for my devotion to the mother who I love so much. Rabbighfirli wa liwalidayya! "(PPC, page 5)

The obedience of my character to his mother is a representation of Islamic values which obliges his servants to always do good, obey and respect their parents, especially to mothers, and it is haram to disobey mother as seen in the Al-Quran and the following Hadiths

Q.S. (4) An-Nisaa': 36 Sembahlah Allah dan janganlah kamu mempersekutukanNya dengan sesuatu pun. Dan berbuat baiklah kepada dua orang ibu-bapa, karibkerabat, anak-anak yatim, orang-orang miskin, tetangga yang dekat dan tetangga yang jauh, teman sejawat, ibnu sabil dan hamba sahayamu. Sesungguhnya Allah tidak menyukai orang-orang yang sombong dan membangga-banggakan diri.

(Depag, tt: 155)

Dari Abu Hurairah ra. Ia berkata, "Seorang laki-laki datang kepada Rasulullah SAW lalu bertanya, 'Siapakah orang yang paling berhak aku perlakukan dengan baik?' Jawab Rasulullah SAW, 'Ibumu!'. Dia bertanya lagi, 'Kemudian siapa ?' Beliau menjawab, 'Ibumu!'. Dia bertanya lagi, 'Kemudian siapa?' Beliau menjawab, 'Kemudian Ibumu!'. Dia bertanya lagi, 'Kemudian siapa ?' Dijawab, 'Kemudian bapakmu!'” (HR. Bukhari 5971. Muslim 2548, dan An-Nawawi 16/80)

(Al-Mundziri, 2017: 723)

Dari Al-Mughirah Ibnu Sa'id ra bahwa Rasulullah SAW bersabda, "Sesungguhnya Allah mengharamkan kepada kalian perbuatan durhaka kepada ibu,..." (HR. Bukhari 2408. Muslim 593, dan An-Nawawi 16/85)

(Al-Mundziri, 2017: 725)

Q.S. (4) An-Nisaa ': 36 Worship Allah and do not associate Him with anything. And do good to two mothers-fathers, intimate-relatives, orphans, poor people, close neighbors and distant neighbors, peers, Ibn Sabil and your companions. Indeed, Allah does not like those who are arrogant and proud.

(Ministry of Religion, $\mathrm{tt}$ : 155)

From Abu Hurairah ra. He said, "A man came to Rasulullah SAW and asked, 'Who is the person I have the most right to treat well?' Rasulullah SAW replied, 'Your mother!'. He asked again, 'Then who?' He replied, 'Your mother!'. He asked again, 'Then who?' He replied, 'Then your mother!'. He asked again, "Then who?" He answered, "Then your father!" (HR. Bukhari 5971. Muslim 2548, and An-Nawawi 16/80)

(Al-Mundziri, 2017: 723) 
From Al-Mughirah Ibn Sa'id ra that Rasulullah SAW said, "Surely Allah forbids you from disobedience to your mother, ..." (Narrated by Bukhari 2408. Muslim 593, and An-Nawawi 16/85)

(Al-Mundziri, 2017: 725)

The obedience of my character to Mother to marry the girl of her mother's choice, although not at all based on love, represents that she is a child who understands, understands and tries to practice the Islamic values that she believes. In the novel 'Fading Pesona Cleopatra', there are three concepts of marriage from different characters.

1. Marriage of a man with a smart and beautiful woman;

2. Marriage of a man to an Egyptian woman, beautiful, smart, unpious, and materialistic;

3. Perninakah a man with a pious woman, smart, memorized alguran, and graceful.

The first concept of marriage, a man with a smart and beautiful woman. They married on the basis of lust because they were deceived by beauty. Pak Agung refuses to marry Zainab, a smart and pious girl, the daughter of a Kiai. He chose to marry Judit Barton. The marriage eventually ran aground. His wife cheated on him with another man. (PPC: 26 - 28)

The concept of the second marriage happened to Mr. Qalyubi who married the Egyptian girl who is famous for her beauty, Yasmin, but does not have a headscarf. Many of his friends have advised not to have any contact with Yasmin because there will be more harm. However, because he was fascinated by Yasmin's beauty, Pak Qalyubi was determined to marry Yasmin. This resulted in prolonged suffering for Pak Qalyubi. The marriage ended tragically. Yasmin asked for a divorce because it was considered that Pak Qalyubi could not comply with everything Yasmin wanted. As a husband, he felt his own wife had trampled his honor. He also regrets that he has deified beauty in choosing a wife. (PPC: 30-39).

The concept of the third marriage occurred in the character Aku and Raihana. He married a pious girl, who was not only graceful, but also kind, smart, educated, and most importantly Raihana memorized the Al Qur'an. It is indeed a fortune for a man who becomes her husband as taught by Islam in determining a life partner/wife.

Q.S. 2, Al-Baqarah: 221 Dan janganlah kamu nikahi wanita-wanita musyrik, sebelum mereka beriman. Sesungguhnya wanita budak yang mukmin lebih baik dari wanita musyrik, walaupun dia menarik hatimu. Dan janganlah kamu menikahkan orang-orang musyrik (dengan wanita-wanita mukmin) sebelum mereka beriman. Sesungguhnya budakyang mukmin lebih baik dari orang musyrik walaupun dia menarik hatimu. Mereka mengajak ke neraka, sedang Allah mengajak ke surga dan ampunan dengan izin-Nya. Dan Allah menerangkan ayatayat-Nya (perintah-perintah-Nya) kepada manusia supaya mereka mengambil pelajaran.

(Depag, tt: 66)

Diriyawatkan dari Abu Hurairah ra. Dari Nabi SAW yang bersabda, "Perempuan itu dinikahi karena empat hal : harta, keturunan, kecantikan, dan agamanya. 
Dapatkanlah wanita yang taat beragama, niscaya engkau beruntung." (HR. Bukhari 5090. Muslim 1466. An-Nawawi 10/41-45)

(Al-Mundziri, 2017: 305)

Q.S. 2, Al-Baqarah: 221 And do not marry idolatrous women, before they believe. Indeed, a slave woman who believes is better than an idolatrous woman, even though she attracts your heart. And do not marry the polytheists (with believing women) before they believe. Surely a slave who believes is better than a polytheist even though he attracts your heart. They invite them to hell, while Allah invites them to heaven and forgiveness with His permission. And Allah explained His verses (His commandments) to people so that they could learn a lesson.

(Ministry of Religion, tt: 66)

Self-preserved from Abu Hurairah ra. From the Prophet SAW who said, "Women are married because of four things: property, descent, beauty, and religion. Get a woman who is devout in religion, you will be lucky. " (HR. Bukhari 5090. Muslim 1466. An-Nawawi 10 / 41-45)

(Al-Mundziri, 2017: 305)

Marriage in the third concept is what happens to my character, although it is not based on the love of my character, but Raihana as the wife shows extraordinary devotion to her husband. Even though the husband's treatment is indifferent, full of pretense and far from sincere love and affection for his wife, Raihana is still full of patience based on sincerity to obey her husband, as stated in Islam. as well as worshiping Allah SWT to gain His blessing, Raihana carried out all of her duties as a wife.

"Aktivitas kami hanya sesekali bertemu di meja makan dan saat sesekali shalat malam." (PPC, hal. 17)

"Perempuan berjilbab yang satu ini memang luar biasa, ia tetap sabar mencurahkan bakti meskipun aku dingin dan acuh tak acuh kepadanya selama ini. Aku belum pernah melihatnya memasang wajah masam atau tidak suka padaku." (PPC:21)

Marriage in the third concept is what happens to my character, although it is not based on the love of my character, but Raihana as the wife shows extraordinary devotion to her husband. Even though the husband's treatment is indifferent, full of pretense and far from sincere love and affection for his wife, Raihana is still full of patience based on sincerity to obey her husband, as stated in Islam. as well as worshiping Allah SWT to gain His blessing, Raihana carried out all of her duties as a wife.

"Our activities are only occasionally meeting at the dining table and the occasional evening prayer." (PPC, p. 17)

"This woman in a veil is indeed extraordinary, she is still patient in devoting her service even though I have been cold and indifferent to her all this time. I've never seen him put on a sour face or dislike me. " (PPC: 21)

What Raihana does to her husband is a representation of Islamic values that a pious wife is a wife who is obedient to worship Allah SWT, who always draws closer and complains about all her problems and sufferings only to Allah.

"Ya Rabbi, tanpa sepengetahuanku, selama dua bulan sebelum aku 
mengantarnya ke rumah ibu mertua ia bahkan sering puasa demi meredam hasrat biologisnya yang tidak pernah kupahami. Ia kuatkan berpuasa demi mensucikan dirinya dari jerat kehinaan. (PPC, hal. 42).

"Yes, Rabbi, without my knowledge, for two months before I escorted him to his mother-in-law's house, he even often fasted to reduce his biological desires that I never understood. He strengthened fasting in order to purify himself from the snare of humiliation. (PPC, p. 42).

The fast that Raihana did was a representation of Islamic values to be oneself in order to avoid humiliation

Diriwayatkan dari Abu Said Al-Kudri, dia berkata," Rasulullah S.a.w. bersabda, "Tidaklah seorang berpuasa selama sehari karena Allah, kecuali dengan puasanya satu hari itu , Allah menjauhkannya dari neraka sejauh tujuh puluh musim'." (HR. Muslim 1153. An-Nawawi 8/220-221) (Al-Mundziri, 2017: 238).

Narrated from Abu Said Al-Kudri, he said, "Rasulullah S.a.w. said, "It is not a person fasting for a day because of Allah, except by fasting that one day, Allah keeps him from hell for seventy seasons". " (HR. Muslim 1153. An-Nawawi 8 / 220-221) (Al-Mundziri, 2017: 238).

Another thing that shows the glory of Raihana's heart can be seen from the letters which are the outpouring of her heart which she wrote and kept to herself, until her husband found and read it.

"Nyaris ia putus asa menanti cairnya cintaku. Beruntung ia memiliki cahaya Alquran di dalam hatinya. "(PPC, hal. 42).

"Rabbi dengan penuh kesyukuran, hamba bersimpuh di hadapan-Mu. Lakal Hamdu ya Rabb. Telah engkau muliakan hamba dengan Alquran. Kau kuatkan diri hamba dengan cahaya Alquran" (PPC, hal. 42).

"Ia lawan badai derita yang menerpanya dengan doa dan latunan ayat suci Alquran." (PPC, hal. 42).

"Almost desperately waiting for my love to melt. Luckily he has the light of the Qur'an in his heart. (PPC, p. 42).

"Rabbi with great gratitude, I kneel before You. Lakal Hamdu yes Rabb. You have honored my servant with the Al Qur'an. You strengthen myself with the light of the Al Qur'an "(PPC, p. 42).

"He fought the storm of suffering that hit him with prayers and recitation of the holy Al Qur'an." (PPC, p. 42).

The outpouring of Raihana's heart which is only addressed to Allah SWT to ask for forgiveness, compassion and help only to Allah is a form of representation of the piety of a wife who realizes and believes that only Allah is the Most Merciful, the best helper (the Most Helper) and the Most Forgiving. It is only in Allah that he puts his trust in him, as stated in the Al Qur'an. 
Q.S.1, Al-Fatihah: 5 Hanya kepada Engkaulah kami menyembah dan hanya kepada Engkaulah kami mohon pertolongan.(Depag, tt: 2)

Q.S. 2, Al-Baqarah: 153 Hai orang-orang yang beriman, mintalah pertolongan (kepada Allah) dengan sabar dan (mengerjakan) salat, sesungguhnya Allah beserta orang-orang yang sabar. (Depag, tt: 45)

Q.S, 3, Ali-Imraan: 102 Hai orang-orang yang beriman, bertakwalah kepada Allah sebenar-benar takwa kepada-Nya; dan janganlah sekali-kali kamu mati melainkan dalam keadaan beragama Islam.

(Depag, tt: 115)

Q.S, 3, Ali-Imraan: 133 Dan bersegeralah kamu kepada ampunan dari Tuhanmu dan kepada surga yang luasnya seluas langit dan bumi yang disediakan untuk orang-orang yang bertakwa.

(Depag, tt: 122)

Q.S, (3) Ali-Imraan: 150 Tetapi (ikutilah Allah), Allahlah Pelindungmu, dan Dialah sebaik-baik Penolong.

(Depag, tt:127)

Q.S.1, Al-Fatihah: 5 Only to you we worship and only to you we ask for help. (Ministry of Religion, $\mathrm{tt}: 2$ )

Q.S. 2, Al-Baqarah: 1530 you who believe, ask for help (to Allah) patiently and (do) prayer, verily Allah is with those who are patient. (Ministry of Religion, tt: 45)

Q.S, 3, Ali-Imraan: 1020 you who believe, fear Allah, you truly fear Him; and do not ever die, but in a Muslim state.

(Ministry of Religion, $\mathrm{tt}: 115)$

Q.S, 3, Ali-Imraan: 133 And hasten you to the forgiveness of your Lord and to the vast heavens as wide as the heavens and the earth prepared for those who fear.

(Ministry of Religion, $\mathrm{tt}: 122$ )

Q.S, (3) Ali-Imraan: 150 But (follow Allah), Allah is your Protector, and $\mathrm{He}$ is the best Helper.

(Ministry of Religion, tt: 127)

The bitter experience experienced by Mr. Agung and Mr. Qalyubi in marriage made my character realize from his dreams so far that worship the beauty of an Egyptian girl who is considered to have the incarnation of Queen Cleopatra. He remembered all the kindness of his wife, Raihana.

"Aku teringat pada Raihana. Perlahan wajahnya terbayang di mata. Sudah dua bulan aku berpisah dengannya. Tiba-tiba ada kerinduan padanya menyelinap dalam hati. Dia isteri yang sangat salehah. Tidak pernah meminta apa pun bahkan yang ada keluar dari dirinya adalah pengabdian dan pengorbanan. Hanya karena kemurahan Allah aku mendapat isteri seperti dia." (PPC, hal 39).

"Diriwayatkan dari Abdullah bin Amr r.a. bahwa Rasulullah SAW bersabda, 'Dunia ialah perhiasan dan sebaik-baiknya perhiasan dunia adalah wanita yang shalihah'." (HR. Muslim 1467. An-Nawawi 10/45).

(Al-Mundziri, 2017: 305) 
"I thought of Raihana. Slowly his face appeared in the eyes. It's been two months I parted with him. Suddenly a longing for him slipped into the heart. She is a very pious wife. Never asking for anything even that which is out of him is a dedication and sacrifice. Only because of the mercy of Allah I got a wife like him. " (PPC, p. 39).

"Narrated from Abdullah bin Amr r.a. that Rasulullah SAW said, "The world is jewelry and the best of the world's jewelry is a woman who is righteous". " (HR. Muslim 1467. An-Nawawi 10/45).

(Al-Mundziri, 2017: 305)

Realizing his mistakes, and being aware of all the kindness, sacrifices and piety of his wife makes the character I want to immediately meet his wife to apologize and regret all that he has done to his wife, and to pour out all the affection he has so far neglected. Unfortunately, what he hoped he did not get. The wife to whom he would devote all his attention and affection has died along with the unborn baby. A belated consciousness that leaves only the futility of life.

\section{CONCLUSION}

Based on the results of the analysis that has been carried out, the following conclusions are obtained. Islamic values contained in the novel 'Faded Pesona Cleopatra' include the values of Akidah, Sharia, and morals. These values are represented in the story in the form of faith in Allah; Faith in the Bible (Al Qur'an) for the value of faith. Sharia values are represented in the form of sunnah fasting; propose (khitbah); wedding; while moral values are represented in the form of personal morals, namely the nature of patience; as well as character in the family which includes obedience and filial piety to parents; pious and obedient to her husband; as well as connecting kinship/friendship ties.

\section{Suggestions}

Suggestions that need to be considered are as follows:

First, suggestions aimed at compilers or authors of books. In writing a fiction book, it would be nice to synergize the material content, language style, good character idealism, skills to invite readers to think critically, magically (to attract and indirectly invite readers) to think creatively, actively, attractively into the story. that it displays.

Second, it is necessary to broadcast outside, displaying text that touches the feeling (amazes the reader) so that it can really make this good story material not only read, but can be enjoyed, lived, and practiced / practiced in real life, Take the positive and get rid of the negativity.

Third, suggestions are given to other researchers. Hopefully the results of this research can become examples of other researchers who are focused, interested, creative and innovative with other literary works, which are beautiful, that are interesting, and motivate readers. What a shame, (eman-eman) if there are many other interesting stories that have not been well studied, which in nature need to be 
disseminated.

Fourth, the aspects of critical, tactical, plastic, and creative thinking in composing stories can be used as additional insights about other similar studies so that this research is used as a material for reference or reference in subsequent research.

\section{REFERENCES}

Abrams, M.H. (1981). A Glossary of Literary Terms. Fourt Ed. New York: Holt, Rinehart and Winston.

Al-Mundziri, Abdul Qawi. (2017). Ringkasan Shahih Muslim. Terj. Pipih Imran Nurtsani, Lc \& Fitri Nurhayati, Lc. Sukoharjo: Insan Kamil.

Arifin, M. (1993). Filsafat Pendidikan Islam. Jakarta: Bumi Aksara.

. Tt. Al-Qur'an Al Karim dan Terjemahnya Departemen Agama. Semarang : Karya Toha Ptra

Casali, D. F. (2017). The Fourteen Elements of Creative Processes, (Online), (https://intenseminimalism.com/2017/the-fourteen-elements-of-creativeprocesses/), diakses 1 Desember 2018.

Erlina, Thahar dan Abdurahman. (2018). "Nilai-nilai Pendidikan dalam Novel 'Mamak' Karya Nelson Alwi. Jurnal Puitika, Vol.14. No.1, April 2018 Hal 1-13. Diakses 12 Juli 2019.

Herimanto dan Winarno. (2008). Imu Sosial dan Budaya Dasar. Jakarta: Bumi Aksara.

https://kbbi.web.id/representasi. Diunduh 10 Mei 2019.

Kusmarwanti. (2005). "Teenlit dan Budaya Menulis di Kalangan Remaja”, dalam Pangesti Widarti (ed). Menuju Budaya Menulis, suatu Bunga Rampai. Yogyakarta: Tiara Wacana.

Muhammad. (2011). Metode Penelitian Bahasa. Yogyakarta: Ar-Ruzz Media

Nurgiyantoro, Burhan. (2013). Teori Pengkajian Fiksi. Yogyakarta: Gajah Mada University Press.

Pradopo, Rachmad Djoko. (1990). "Penelitian Sastra Indonesia”. Jakarta: Makalah Kongres Bahasa Indonesia $V$, Pusat Bahasa. (2003). Beberapa Teori Sastra, Metode Kritik, dan Penerapannya. Yogyakarta: Pustaka Pelajar.

Ratna, Nyoman Kutha. (2006). Teori, Metode, dan Teknik Penelitian Sastra. Yogyakarta : Pustaka Pelajar.

Sayuti, Suminto. A. (2000). Berkenalan dengan Prosa Fiksi. Yogyakarta : Gama Media.

Sukardi. (2013). Metodologi Penelitian Pendidikan: Kompetensi dan Praktisnya. Jakarta: PT Bumi Aksara.

Wellek, Rene dan Austin Werren. (1993). Teori Kesusastraan. Terj. Melanie Budianta . Jakarta:Gramedia.

Wijaya, Heru Santosa. (2012). Pengantar Apresiasi Prosa. Surakarta : Yuma Pustaka. 
Volume 4 Number 4 June 2021

Yuwono, Untung. (2007). Gerbang Sastra Indonesia Klasik. Jakarta : Wedatama Widya Sastra. 